\title{
Organisational Leadership in Bangladesh: An Investigation of Managerial Response to A Change Environment
}

\author{
Christopher Selvarajah \\ Swinburne University of Technology \\ E-Mail: cselvarajah@swin.edu.au \\ Denny Meyer \\ Swinburne University of Technology \\ E-Mail: dmeyer@swin.edu.au \\ Tarun Kanti Bose \\ Khulna University \\ E-Mail: tarun84ku@yahoo.com
}

\begin{abstract}
This paper examines links between the cultural embeddedness and current managerial response to leadership excellence in a change environment in the context of Bangladesh. The study was performed for the years of 2009 and 2014. To explore the link between culture and managerial response, factor analysis, regression and structural modelling using SPSS V22 and AMOS V22 are employed to explain what constitutes managerial leadership excellence in Bangladesh. The results, based on the perceptions of 660 Bangladesh managers, suggest that managers are receptive to behavioural changes demanded by the environment. In particular, empathy has a negative relationship with the Excellent Leader response in 2014 compared to 2009, thus suggesting environmental changes influencing managerial behaviours. Future research should explore further the time and etic influences on leadership.
\end{abstract}

Keywords: Managerial Leadership, Human Capacity Building Sufi Islam, Environment Sustainability, Empathy 


\section{INTRODUCTION}

In the business context, managers are entrusted as leaders to develop work skills to reflect changes and ensure organizations' survival. However, growing interest in sustainable development has illuminated organizations' obligation to uphold corporate social responsibility principles in the context of national and global development. In recent studies, despite very little critical research establishing these claims, this interest is based on claims that both leadership and culture are linked to organisational performance both in the public and private sectors (Belias and Koustelious, 2014; Berman and Prasojo, 2018; Nie, Xiao and Barsoux 2017; Rowley and Ulrich 2014; Rowley and Warner, 2006). Furthermore, there is a lack of interest and, as such, critical research to establish environmental influences of social change, both in national and international 'shocks' and effects over which the organisations have very little control but that will affect their performance as managers in a leadership capacity.

The lack of interest in the effects of the environmental influences are due to the complexity in pursuing longitudinal studies to determine cause and effect (Allen, Feier, and Strachan, 2004). As Howitt and Cramer (2011) assert, cause and effect must be shown if the cause precedes the effect and in which results show that there is substantial evidence for community outcome and cognition being longitudinally linked.

In this paper, we study the effects of change on managerial leadership behaviours during two survey years: 2009 and 2014. As mentioned, recent studies have highlighted the importance of the cultural context influencing managerial leadership, and this paper takes the view that managerial leadership is based on pragmatism and that changes in the environment are reflected in the manner in which managers lead. This paper tests the Global Financial Crisis (GFC) as an effect on organisational performance through hypotheses formulated to study managerial leadership responses between 2009, ${ }^{1}$ when its effect was felt in Bangladesh, and 2014, when the effect was at its height. Though the GFC was first felt globally in 2007, its initial impact was on developed nations and less on nations such as Bangladesh, where the nation's capital account was not liberalised and exposed internationally. The effect of the GFC in the developed nations of Europe and in the US cascaded down to Bangladesh mainly through exports, remittances, and imports stating in mid-2009, and it intensified in the next few years (Murshid, et al., 2009; Rahman, 2014).

\footnotetext{
${ }^{1}$ The GFC is said to have had a lagged effect on Bangladesh (Battacharya, Dasgupta, and Neethi,
} 2012) 


\section{SOCIO-POLITICAL BACKGROUND OF BANGLADESH}

Bangladesh is a South Asian country which, prior to 1947, was part of the British colony that included India. With the partition of India in 1947, the former British Raj was divided, on one part with the majority of the Hindu population in India and on another part with the majority of the Muslim population in Pakistan, an Islamic nation. From 1947 to 1971, Bangladesh, then called East Pakistan, was the eastern territory of the newly formed nation of Pakistan, and East Pakistan eventually became an independent country in 1971 after its secession from Pakistan (Alam, 1993; Hassan, 2012). The country has had periods of military rule - between 1975 and 1990 when a military coup with backing from Islamist groups assassinated Prime Minister Sheikh Mujibar Rahman, and again between 2006 and 2008 (Hassan, 2012). Currently it has a population of more than 160 million people and is ranked eighth in the list of the world's most populous countries. Bangladesh is mainly surrounded by India with one small border with Myanmar, facing the Bay of Bengal to the south.

Bangladesh's economy and culture are based on the values of an agrarian society, with dependence on the River Ganges delta plains. However, in the last few years, rapid industrialization coupled with an increasing exodus of people going abroad for employment have brought rapid change to the economic and social structure of the country (GED, 2016; Bangladesh Economic Update, 2016). Agriculture is still the country's main revenue source, followed by the garment industry (Bangladesh Economic Update, 2016; Rahman and Salim, 2013). Recently, with income flowing in from Bangladeshis employed as workers in foreign countries and from the garment industry, economic growth has spurred changes to the social system and also in residents' lifestyle, particularly that of the younger generations (Khan, 2005; Bangladesh Economic Update, 2016). Like most Asian and South Asian countries, the Bangladeshi culture is high context (Riaz, 2004; Ahmed, 2011). Bangladeshis are highly engaged in formalities and in social orientations affecting both government and private organizations.

Based on this history, it is expected that leadership excellence in Bangladesh organisations will be influenced by recent geopolitical events such as the war of independence, Bangladesh's dependence on export revenue, the country's common cultural inheritance with India, and the influence of Islamic values. The following section will focus on the position of culture in leadership and management in Bangladesh and the development of the hypotheses. 


\section{THE THEORETICAL FRAMEWORK FOR EXCELLENT LEADERSHIP}

In reference to the universality of management style, Morishita (2001), a Japanese scholar, stated that management style and cultural uniqueness are linked and that applying management style to an organizational setting without taking into account the uniqueness of its culture would cause friction in organizational operations. In a recent study, Patel, Salih, and Halim (2018) have emphasised the need to capture the uniqueness of the context informed by indigenous frameworks rather than the frameworks developed from western theoretical constructs. Just as each country exhibits its own management style, in Asia there is diversity in management, and needless to say, Bangladesh has its own unique culture that informs and influences managerial behaviour in its organisations. In this paper, it is posited that geopolitical events, which are extrinsic to the organisation (etic) and those that are cultural, viewed as intrinsic (emic), are expected to influence managerial behaviours. The culturespecific influences develop because of specific socio-economic conditions unique to the environment, while the universal influences are those that can be easily transferred, as these values are not determined by the socio-economic condition of the environment. These etic values are often the first step in integrating local human resources to imported systems such as those of foreign multinational companies.

Failure to understand geopolitical influences and cultural imperatives, which underpins organizational behaviours, has led to disastrous outcomes (Jones and Matthew, 2012). Jones and Mathew (2012) explain in their research of the Toyota operation in India that the imposition of Japanese values in the Toyota factory in India has been resisted, as many of the unique features of Japanese management are alien to the Indian culture and therefore Indian behaviour. A similar effect on local culture was observed by Choudhury (2000) in the case study of Honda and its joint venture with Hero Honda in India.

The culture-affected conditions that influence organizational behaviour must be approached with caution. Where culture-specific conditions affect management practices, these practices necessitate a change in the mindset of managers to avoid alienation of local labour and to increase acceptance of organisational operations.

From the above discussion, it can be said that the application of the etic value system alone in a unique cultural environment can cause friction and animosity, as explained by Jones and Mathew (2012). Culture does play an important role in determining management culture/practices. The understanding of the uniqueness of the organizational environment encourages empathy for excellence in managerial practices in organisations. Thus, the framework of Excellence in Leadership (EIL), 
proposed by Selvarajah et al. (1995), was employed in this study, which is well informed by the Asian cultural context.

Selvarajah et al. (1995) developed their EIL model in order to theorise leadership excellence in Asia and identified four behavioural dimensions of an excellent leader: personal qualities, environmental qualities, organisational demands, and managerial behaviours. With the inclusion of excellent leadership, the five-construct model has been applied to describe managerial leaders in Asia including Cambodia (Selvarajah, Meyer, \& Davuth, 2012), China (Selvarajah \& Meyer, 2008b), Indonesia (Selvarajah \& Meyer, 2017), Malaysia (Selvarajah \& Meyer, 2006; 2008a), Singapore (Selvarajah, Meyer, Jeyakumar, \& Donovan, 2013a), India (Selvarajah et al., 2014), and Thailand (Selvarajah, Meyer, \& Donovan, 2013b). The five constructs, which are central to the EIL framework, are defined below (excerpted from Selvarajah, Meyer, \& Donovan, 2013a: 359):

Excellent Leadership describes the combination of behaviours and attitudes desirable for good leadership within a certain cultural context. Environmental Influences are external factors that influence the success of the entire organisation. They emphasise the importance of scanning and evaluating the external environment for opportunities. Personal Qualities are the personal values, skills, attitudes, behaviours, and qualities of an individual. They emphasise morality, religion, inter-personal relationships, and communication. Organizational Demands are the ways a manager responds to the goals, objectives, structures, and issues in an organisation. They emphasise the importance of organisational prosperity. Managerial Behaviours include a person's nature, values, attitudes, actions, and styles when performing managerial duties. They emphasise a centralised as opposed to participative work orientation.

In the following section, we explore the cultural values underpinning Bangladesh society that influence managerial behaviours. In so doing, we develop hypotheses for testing the unique cultural framework that drives managerial behaviours in Bangladesh organizations. 


\section{Nationhood Ideals}

Bangladesh, like many post-colonial economies, have progressively evaluated their nationhood ideals. Wood (2007) describes the early post-colonial era as decades in which universal discourse took place, abstracted from the experiences of industrialised wealthy metropolitan democracies. With little experience in selfgoverning, many post-colonial economies automatically assumed and experimented with a liberal democratic pluralistic agenda. Wood (2007) argues that the former colonial nations, such as Bangladesh, have moved into a post/post-colonial discourse in which the structure of authentic knowledge about development is purely not economistic materialism but a re-distributed network model with a multiplicity of sites of discourse. Based on this understanding, the first hypothesis is presented.

H1. Bangladesh managers emphasise a multiplicity of values that reflect personal, managerial, organisational, and environmental dimensions of leadership excellence.

\section{Effect of Islamic Values on Managerial Leadership Excellence}

Bangladesh has fought its own ideological battles for an ethnic-based nationalism over a religious one. However, as the majority of the population are of the Islamic faith, there is a constant reminder that secularism in Bangladesh is valued as long as Islam is honoured. Bangladesh (former state of East Pakistan) was founded in 1971 as a secular state after a very bloody war with West Pakistan. In 1977, Islam was made the state religion by the military government of General Ershad, but the High Court in 2010 upheld the secular principles of the 1972 constitution.

On the whole, Bangladeshis are hierarchical, and their daily lives seldom overlap with people of higher rank (Bertocci, 2006). However, in their religious obligations, they exhibit anti-structural liminality (Turner, 1969), and as Bertocci (2006) observes, they are strengthened by their liberal religious views. Bertocci (2006:2) recognises that "Bangladeshi Islam of late displayed an authoritarian and militant face." However, he is of the view that, despite the outward evidence of literalist and political Islam, one cannot ignore the deeply rooted moderating secular values prevailing in society.

Sufi Islam is viewed as the inner mystical dimension of Islam, seeking ihsan or perfection (Zarruq, Istrabadi, Hanson, 2008). Certain aspects of Sufi philosophy are controversial and are often debated. Chief among them are abandoning materialism and living only for praying, something similar to monasticism, and the Sufis follow their own spiritual leaders (Suwaydan, 2000). Different movements of Islamic culture like the Maijbhandari movement has some influence in the entire Bangladesh urban- 
rural and socioeconomic spectrum (Bertocci 2006). This Sufi movement has developed sapta paddhati or seven steps based on self-discipline for the attainment of spiritual perfection. These steps or principles are individualistic in nature and unique. These principles inform incremental development of knowledge to improve performance. In addition, the religious structure of the society (whether it is Islam or Hindu) places value on liberalism and dualism and urges people to live peacefully with each other. Based on this view, to seek self-improvement, the following hypothesis is tested.

H2. An excellent leader in the Bangladesh organization is driven to continuously improve performance.

Though it is doubtful that the ordinary citizen is drawn to the rigorous austerities of these steps (Bertocci 2006), the managerial values as expounded in the above hypotheses translate from the objectives of the seven incremental steps of Sufi Islam as practiced in Bangladesh.

An aspect of the Sufi movement in Bangladesh that has drawn communal interest is the use of musical performance as a mode of worship (Lawrence, 1983). This musical appeal is also found in the non-Islamic population in Bangladesh (Rahman, 2014). Furthermore, Hodge (2005) asserts that liberal religious values are based on communal interdependence that enshrines community, connectedness, consensus, community actualization, group achievement and success, community reliance, respect for community rights, self-control, sensitivity to group oppression, implicit communication that safeguards others' opinions, and complementary gender roles.

Based on the influence of the broad secular form of Sufi Islam, tolerance towards all religious groups is viewed as being highly inclusive. Therefore, based on this understanding, the following hypothesis is presented for testing.

H3. There is no difference between the religious groups' perception of what constitutes excellence in leadership in Bangladesh.

Therefore, though Islam is the basis of the Bangladesh belief system, the secular nature of the society exhibits a highly tolerant society. Based on this understanding, the following hypothesis is presented for testing.

H4. An excellent leader in Bangladesh organisations exhibits values that are empathic to the feelings of the community. 
Hague (2007) states that leadership is an important part of organisational development and its contribution in any society can be approached with reference to managerial and political contexts. In these contexts, managers are seen as leaders of business organisations while public servants are seen as "associational" leaders (Hall, 1991: 52) who administer public service. Therefore, much of the literature on leadership is about the traits, roles, and effectiveness of leaders as managers and associational leaders in management and public administration, respectively (Hague, 2007).

In developing countries, national prosperity rests on the performance of both public and private sector development and, as such, leadership in both of these sectors is important. Terry (2015) convincingly argues the importance of administrative leadership in the mobilisation of relevant people and resources to achieve the objectives of public bureaucracies. Unlike developed countries, where the bureaucracy is viewed at arm's length, developing countries take a much more active role (Thai and Carsten, 2015). In countries such as Bangladesh, with a tendency for centralisation of power, the bureaucracy has a much greater role in national progress, compared to western democratic nations (Salahuddin et al., 2008). Hague (2007) states, "in Bangladesh, public affairs have generally been dominated by the government and political parties, with input from bureaucracy and military” (p. 234). The centralisation of power is no doubt an exposé of Bangladesh's traditional culture as a highly hierarchical society in which deference toward the socially superior and non-confrontational approach are accepted norms. Khan (1999) asserts that, in developing countries such as Bangladesh, local leadership is related to the cultural aspects of power and authority. These aspects of power and authority in Bangladesh are vested in such authority bases as (1) elderly or senior village headmen, (2) communal dispute settlers, (3) village politicians, and (4) people acknowledged as men of honour.

A third element of leadership, especially with a balanced nation building emphasis, is the emergence and contribution of civil society, namely the nongovernmental organisations (NGOs). This third element, contributing to national development, is a relatively new phenomenon in Bangladesh (Hague, 2007). The proliferation of NGOs in Bangladesh has strengthened the civil society and, in some ways, counters the failure of the national system of government. The NGOs, which are mainly located in urban areas in Bangladesh, are seen to be taking an increasingly proactive role in public affairs. 
These three groups from business, government, and civil society form the basis within which managerial leadership in Bangladesh is perceived.

H5. Managerial leadership in Bangladesh organisations is influenced by relationshipbased managerial behaviours and good communication skills.

\section{Effect of Environmental Changes on Managerial Leadership Excellence}

In this paper, we also posit that the unique features of leadership behaviours in Bangladesh are influenced by extrinsic factors that are geopolitical in nature and intrinsic factors that are cultural in nature. Observable extrinsic factors affecting Bangladesh managers that may influence their behaviours are (1) the effect of the GFC on business specifically and the economy generally and (2) the impact of the war of independence that has become the focus of Bangladesh's vision for a progressive and survival-oriented nation.

When the 2009 study was conducted, the effect of the GFC was just becoming felt in Bangladesh. Murshid (2009) reported that, based on the Bangladesh Bureau of Statistics (BBS) figures, a 5.9\% growth rate for the year 2008-09 was recorded; most observers felt that this was commendable performance against the backdrop of the GFC following sharp fluctuations in world food and fuel prices, high inflation levels, and low investor confidence. A similar sentiment was expressed by Mukherjee and Pratap (2009) when they reported, "Bangladesh economy proved to be one of the most resilient in the world to the fallout from the global financial crisis, with GDP growth in FY 2008/9 only declining to 5.9\% from 6.2\% in FY 2007/8. GDP growth is expected to be 5.5 in FY10" (p. 154). This optimism was further echoed by others, especially when the duration, depth, and severity of the global GFC were expected to be minor (Imam, 2009). There was, however, concern that Bangladesh had concentrated its exports with more than $90 \%$ reliance on the USA and the EU, with $75 \%$ of these exports consisting of ready-made garments (Islam and Quddus, 2008). The GFC concerns became real only when it was realised that Bangladesh had become highly globalised, though as noted by Mansur (2011); Ali, Islam, and Wise (2011); Reza and Khan (2011); and Ali and Islam (2010), Bangladesh came out of the GFC relatively unscathed.

Therefore, the sense of security that would have been exhibited by organisations at the early stages of the GFC to that of the GFC aftermath are expected to differ. This could, in fact, be seen as a learning experience. As Mansur (2011) expressed, the Bangladesh economy is relatively undeveloped, but as it becomes integrated with the global economy through trade, the deterioration in the external environment, 
especially its western markets, will impact the Bangladesh economy. Based on this understanding, the following hypotheses are suggested.

H6. As the GFC impacts the Bangladesh economy, the responses of managers to leadership excellence will differ between 2009 and 2014.

H7. With increased globalisation exposure, Bangladesh's organisational managers will become less emphatic.

H8. Managers from the 2014-year sample will associate excellence in leadership more strongly with EI-related dimension than will the managers from the 2009-year sample.

\section{RESEARCH METHODOLOGY}

Selvarajah et al. (1995) developed 94 "excellence in leadership" value statements using the ten most important statements to measure the construct of excellent leader (EL). They then divided the statements between the four categories of personal qualities (PQ), managerial behaviours (MB), organisational demands (OD), and environmental influences (EI) using Q-Sort. In the current study, these ninety-four statements were included in a survey of 440 managers in Bangladesh in 2009 and 220 managers in 2014. The 2009 survey was carried out largely in Decca and Chittagong, while the 2014 survey was carried out in Khulna. The response rates for the 2009 and 2014 surveys were $68 \%$ and $79 \%$, respectively.

The managers in the survey ranked the 94 items based on the importance of being an excellent leader in Bangladesh organisations on a Likert scale of one to five, five denoting most important and one denoting least important

In this paper, the data was analysed developing summated scales for the five constructs of EL, PQ, MB, OD, and EI using most of the value statements sorted by Selvarajah et al. (1995) and several other value statements rated highly in the current study. As reported in the appendix tables (A1 to A5), confirmatory factor analysis, Cronbach's alpha, and a composite reliability measure are used to check the internal validity and the reliability of the scales, respectively. Models which produce a root mean squared error of approximation (RMSEA) of less than 0.08, a goodness of fit statistic (GFI) of above 0.90, and a normed chi-squared statistic (CMIN/DF) of between one and three are regarded as valid (Arbuckle and Wothke, 1999). Scales with a Cronbach's alpha of above 0.70 are regarded as reasonably reliable, with values above 0.80 indicating good reliability. Values of above 0.60 are considered adequate for an exploratory study such as this (Hair, Black, Babin, Ednerson and Tatham, 2006). 
Similarly, values of above 0.60 are considered adequate for composited reliability (Hair, Hult, Ringle, and Sarstedt, 2017), even when the average variances extracted are low (Fornell and Larcker, 1981). The first hypothesis tests the Figure 1 model using the above scales. Multivariate and univariate analyses of variance are employed to test the remaining hypotheses to test for effects on the scales. SPSS v22 and AMOS v22 are the software packages used for the above analyses.

\section{Statistical Analysis}

Descriptive statistics were presented for demographic and scale variables, and a Multivariate Analysis of Variance was used to test for significant differences between the demographic groups and, in particular, for differences between the 2009 and 2014 surveys. A regression analysis suggested which scales were directly related to leadership excellence, and a structural model was used to test for invariance across the two survey years and to assess the importance of each scale as a predictor of leadership excellence for each of the years.

\section{RESULTS}

Across the 2009 and 2014 samples, only 13\% were women and $67 \%$ of the respondents were less than 35 years old. Most (60\%) of the managers were employed in private businesses, with $21 \%$ in government organisations and $20 \%$ in NGOs. Large companies with over 1000 workers were represented by $28 \%$ of the participants, with $18 \%$ of the managers coming from small companies employing under 50 employees, $35 \%$ with $50-100$ employees, $58 \%$ with $100-500$ employees, and $72 \%$ with 500-1000 employees. Only $11 \%$ of the managers worked in departments with more than 100 employees, with $34 \%$ working in departments with up to 10 employees, $65 \%$ in departments with up to 25 employees, $79 \%$ in departments with up to 50 employees, and $89 \%$ in departments with up to 100 employees. Middle managers comprised $55 \%$ and line managers comprised $29 \%$ of the participants, with $14 \%$ of the sample classifying themselves as senior managers. The majority $(89 \%)$ of the respondents gave their religion as Islam, with $10 \%$ claiming Hinduism.

There were significant differences between the demographic composition of the survey samples in the two periods (2009 and 2014) as presented in Table 1; however, there were no significant differences in terms of gender balance, with low percentages of women (14\% and 11\%) recorded in both 2009 and 2014, respectively. Clearly the 2009 sample was based largely on the private industry sector, while the 2014 sample was mostly spread between government and NGOs. The 2009 sample was younger 
than the 2014 sample, with a higher percentage of small organisations but larger departments represented than in the 2014 sample. In the 2014 period, Hinduism was slightly more prominent than in the 2009 sample. All of these factors suggest that there will be differences between these two sample years. This means that these factors should to the extent possible be controlled before any comparison of the 2009 and 2014 participants is attempted.

Table 1 Demographic Composition of Survey Samples

\begin{tabular}{|c|c|c|c|c|}
\hline & & $\begin{array}{c}2009 \text { Sample } \\
\% \\
\end{array}$ & $\begin{array}{c}2014 \text { Sample } \\
\% \\
\end{array}$ & $\begin{array}{l}\text { Combined } \\
\text { Sample \% } \\
\end{array}$ \\
\hline \multirow{6}{*}{ Industry } & Private & 85 & 5 & 60 \\
\hline & Government & 10 & 44 & 21 \\
\hline & NGO & 5 & 51 & 19 \\
\hline & Senior manager & 16 & 10 & 14 \\
\hline & Middle Manager & 60 & 52 & 57 \\
\hline & Line Manager & 24 & 38 & 29 \\
\hline \multirow{3}{*}{ Age } & Less than 35 & 75 & 53 & 67 \\
\hline & $35-40$ & 11 & 32 & 18 \\
\hline & More than 40 & 14 & 15 & 15 \\
\hline \multirow{5}{*}{ Size Organisation } & Under 51 & 26 & 4 & 18 \\
\hline & $51-100$ & 19 & 12 & 17 \\
\hline & $101-500$ & 20 & 28 & 23 \\
\hline & $501-1000$ & 11 & 19 & 14 \\
\hline & Over 1000 & 24 & 38 & 28 \\
\hline \multirow{3}{*}{ Size Department } & Under 11 & 38 & 27 & 34 \\
\hline & $11-25$ & 31 & 30 & 31 \\
\hline & More than 25 & 31 & 43 & 35 \\
\hline \multirow{2}{*}{ Religion } & Islam & 94 & 80 & 90 \\
\hline & Hinduism & 6 & 20 & 10 \\
\hline
\end{tabular}

Summated scales were calculated for each construct, and the descriptive statistics, Cronbach's alpha, the square root of the average variance extracted ( $\sqrt{ }$ Ave), and the correlations shown in Table 2 were computed. All of the correlations are moderate in size except for weak correlations with the Empathy scale. The reliability of all scales is reasonable (Cronbach's alpha and Composite Reliability greater than 0.60 ) for a study of this nature, although average variances extracted (AVE) are low. 
Table 2 Descriptive Statistics and Correlations for Scales

\begin{tabular}{|c|c|c|c|c|c|c|}
\hline & $(1)$ & $(2)$ & (3) & (4) & $(5)$ & $(6)$ \\
\hline Mean & 4.40 & 4.12 & 4.28 & 4.19 & 4.28 & 3.54 \\
\hline Standard Deviation & .52 & .58 & .53 & .52 & .54 & .82 \\
\hline Cronbach Alpha & .778 & .766 & .608 & .825 & .706 & .695 \\
\hline$\sqrt{ }$ Ave & .555 & .524 & .509 & .461 & .495 & .565 \\
\hline Composite Reliability & .779 & .769 & .613 & .829 & .717 & .697 \\
\hline 1.Excellent Leader & 1 & $.686^{* *}$ & $.700^{* *}$ & $.713^{* *}$ & $.703^{* *}$ & $.260^{* *}$ \\
\hline 2.Environmental Influence & $.686^{* *}$ & 1 & $.696^{* *}$ & $.734^{* *}$ & $.688^{* *}$ & $.220^{* *}$ \\
\hline 3.Organisational Demand & $.700^{* *}$ & $.696^{* *}$ & 1 & $.615^{* *}$ & $.568^{* *}$ & $.194^{* *}$ \\
\hline 4.Managerial Behaviour & $.713^{* *}$ & $.734^{* *}$ & $.615^{* *}$ & 1 & $.777^{* *}$ & $.273^{* *}$ \\
\hline 5.Communication & $.703^{* *}$ & $.688^{* *}$ & $.568^{* *}$ & $.777^{* *}$ & 1 & $.254^{* *}$ \\
\hline 6.Empathy & $.260^{* *}$ & $.220^{* *}$ & $.194^{* *}$ & $.273^{* *}$ & $.254^{* *}$ & 1 \\
\hline
\end{tabular}

\section{MANOVA Analysis}

The MANOVA test results shown in Table 3 show significant but small differences for age. Similarly, there is no significant difference between religious groups' perception of managerial excellence in Bangladesh, thus supporting the third hypothesis. However, the effect of survey year was much stronger, even when all the other demographic variables were controlled, thus supporting the sixth hypothesis. Hypothesis 6 was developed to measure if the effect of GFC had influenced differences in managerial leadership perceptions between the survey years.

As shown in Table 4, only in the case of Environmental Influence does age have a significant effect, with those over 50 years of age considering this to be a relatively unimportant area compared to the other age groups.

As shown in Table 5, there has been a very obvious decline in Empathy between 2009 and 2014, thus supporting Hypothesis 7. There appears to be less room for interpersonal relations and informality in 2014 than there was in 2009 . However, there has also been a slight but significant decline in the importance of excellent leadership and communication when the demographic factors were controlled. Consequently, it can be assumed that it is not just demographic differences that account for the differences in perceptions of the importance of excellent leadership, communication, and empathy for the two years surveyed. 
Table 3 MANOVA Comparison of Demographic Groups

\begin{tabular}{|c|c|c|c|c|c|}
\hline \multirow[b]{2}{*}{$\begin{array}{l}\text { Demographic } \\
\text { Variable }\end{array}$} & \multicolumn{3}{|c|}{ MANOVA Test - Using Wilks Lambda } & \multirow[b]{2}{*}{ p-value } & \multirow{2}{*}{$\begin{array}{l}\text { Partial eta- } \\
\text { squared }\end{array}$} \\
\hline & $\begin{array}{c}\text { Numerator } \\
\text { df1 }\end{array}$ & $\begin{array}{c}\text { Denominator } \\
\text { df } 2\end{array}$ & $\mathrm{~F}(\mathrm{df} 1, \mathrm{df} 2)$ & & \\
\hline Gender & 6 & 553 & 1.60 & .145 & .017 \\
\hline Industry & 12 & 1106 & 1.45 & .136 & .016 \\
\hline Position & 12 & 1106 & 1.22 & .266 & .013 \\
\hline Age & 24 & 1930 & 2.17 & .001 & .023 \\
\hline $\begin{array}{l}\text { Organization } \\
\text { Size }\end{array}$ & 24 & 1930 & 1.48 & .062 & .016 \\
\hline $\begin{array}{l}\text { Department } \\
\text { Size }\end{array}$ & 24 & 1930 & 1.47 & .070 & .016 \\
\hline Religion (*) & 6 & 553 & 1.65 & .134 & .017 \\
\hline Survey Year & 6 & 553 & 11.85 & $<.001$ & .110 \\
\hline
\end{tabular}

(*) Considering only Islam and Hinduism

Table 4 Comparison of Mean Scale Values Across Age Groups

\begin{tabular}{|c|c|c|c|c|c|c|c|c|}
\hline & \multicolumn{5}{|c|}{ Mean (Standard Deviation) } & \multicolumn{3}{|c|}{ F-Test } \\
\hline & $<35$ & $35-40$ & $40-45$ & $46-50$ & $>50$ & $\mathrm{~F}(1,558)$ & $\mathrm{p}$-value & $\eta^{2}$ \\
\hline & $\mathrm{N}=441$ & $\mathrm{~N}=119$ & $\mathrm{~N}=58$ & $\mathrm{~N}=21$ & $\mathrm{~N}=15$ & & & \\
\hline 1. Excellent Leader & $\begin{array}{l}4.42 \\
(.52)\end{array}$ & $\begin{array}{l}4.39 \\
(.50)\end{array}$ & $\begin{array}{r}4.26 \\
(.58)\end{array}$ & $\begin{array}{l}4.32 \\
(.46)\end{array}$ & $\begin{array}{l}4.26 \\
(.46)\end{array}$ & 1.66 & .157 & .012 \\
\hline $\begin{array}{l}\text { 2. Environmental } \\
\text { Influence }\end{array}$ & $\begin{array}{l}4.13 \\
(.58) \\
\end{array}$ & $\begin{array}{l}4.17 \\
(.51) \\
\end{array}$ & $\begin{array}{r}4.10 \\
(.65) \\
\end{array}$ & $\begin{array}{r}4.07 \\
(.55) \\
\end{array}$ & $\begin{array}{l}3.62 \\
(.74) \\
\end{array}$ & 3.14 & .014 & .022 \\
\hline $\begin{array}{l}\text { 3. Organisational } \\
\text { Demand }\end{array}$ & $\begin{array}{l}4.29 \\
(.57) \\
\end{array}$ & $\begin{array}{l}4.31 \\
(.54) \\
\end{array}$ & $\begin{array}{l}4.27 \\
(.70) \\
\end{array}$ & $\begin{array}{l}4.19 \\
(.43) \\
\end{array}$ & $\begin{array}{l}3.97 \\
(.51) \\
\end{array}$ & 1.02 & .396 & .007 \\
\hline $\begin{array}{c}\text { 4.Managerial } \\
\text { Behaviour }\end{array}$ & $\begin{array}{l}4.19 \\
(.52) \\
\end{array}$ & $\begin{array}{l}4.25 \\
(.50) \\
\end{array}$ & $\begin{array}{l}4.15 \\
(.48) \\
\end{array}$ & $\begin{array}{l}4.17 \\
(.48) \\
\end{array}$ & $\begin{array}{l}3.99 \\
(.59) \\
\end{array}$ & 1.81 & .125 & .013 \\
\hline 5.Communication & $\begin{array}{l}4.29 \\
(.55) \\
\end{array}$ & $\begin{array}{l}4.31 \\
(.47) \\
\end{array}$ & $\begin{array}{l}4.22 \\
(.57) \\
\end{array}$ & $\begin{array}{l}4.12 \\
(.44) \\
\end{array}$ & $\begin{array}{r}4.00 \\
(.66) \\
\end{array}$ & 1.73 & .142 & .012 \\
\hline 6.Empathy & $\begin{array}{l}3.64 \\
(.75)\end{array}$ & $\begin{array}{l}3.21 \\
(.93)\end{array}$ & $\begin{array}{l}3.47 \\
(.92)\end{array}$ & $\begin{array}{l}3.62 \\
(.83)\end{array}$ & $\begin{array}{r}3.32 \\
(.78)\end{array}$ & 2.34 & .054 & .016 \\
\hline
\end{tabular}


Table 5 Comparison of Mean Scale Values for Survey Years

\begin{tabular}{lccccc}
\hline & \multicolumn{2}{c}{ Mean (Standard Deviation) } & \multicolumn{3}{c}{ F-Test } \\
\cline { 2 - 6 } Scale & $\begin{array}{c}2009 \\
\mathrm{~N}=440)\end{array}$ & $\begin{array}{c}2014 \\
(\mathrm{~N}=220)\end{array}$ & $\mathrm{F}(1,556)$ & $\mathrm{p}$-value & $\eta^{2}$ \\
\hline 1.Excellent Leader & $4.48(.50)$ & $4.22(.53)$ & 9.29 & .002 & .016 \\
\hline $\begin{array}{l}\text { 2.Environmental } \\
\text { Influence }\end{array}$ & $4.15(.57)$ & $4.06(.59)$ & .76 & .382 & .001 \\
\hline $\begin{array}{l}\text { 3. Organisational } \\
\text { Demand }\end{array}$ & $4.30(.58)$ & $4.25(.55)$ & .01 & .911 & .000 \\
\hline $\begin{array}{l}\text { 4.Managerial Behaviour } \\
\text { 5.Communication }\end{array}$ & $4.24(.50)$ & $4.10(.53)$ & 3.34 & .068 & .006 \\
\hline 6.Empathy & $4.35(.53)$ & $4.13(.53)$ & 4.81 & .029 & .009 \\
\hline
\end{tabular}

\section{Regression Analysis}

The following regression explains $64 \%$ of the variation in excellent leader scores. Note the significant coefficient for year, indicating that, on average, the importance of leadership excellence declined by 0.149 between 2009 and 2014 when the effect of the other scales was controlled. Only in the case of the empathy scale was there no significant direct influence on the importance of excellent leadership when the other predictors, including survey year, were controlled.

Table 6 Linear Regression Model for the Importance of Leadership Excellence

\begin{tabular}{lccccc}
\hline & \multicolumn{2}{c}{ Unstandardised Coefficients } & $\begin{array}{c}\text { Standardised } \\
\text { Coefficients }\end{array}$ & t-value & p-value \\
\cline { 2 - 4 } & $\mathrm{B}$ & Standard Error & Beta & & \\
\hline Constant & .887 & .120 & & & \\
Year & -.149 & .029 & -.135 & -5.076 & $<.001$ \\
Environmental Influence & .199 & .034 & .221 & 5.898 & $<.001$ \\
Organisational Demand & .198 & .029 & .217 & 6.894 & $<.001$ \\
Managerial Behaviour & .224 & .043 & .221 & 5.182 & $<.001$ \\
Communication & .224 & .038 & .231 & 5.835 & $<.001$ \\
Empathy & -.002 & .017 & -.003 & -.095 & .924 \\
\hline
\end{tabular}

The structural model shown in Figure 2 explained $67 \%$ of the variation in the excellent leader perceptions. In this model, managerial behaviour and communication 
have been combined to construct a second-order model for managerial leadership, taking into account the very strong correlation between these two scales. The model clearly demonstrates that the perceptions of what constitutes an excellent leader in Bangladesh can be well explained in terms of the dimensions of environmental influences, managerial behaviours, organisational demands and personal qualities, as reflected through empathy and communication. Furthermore, all of the links shown in this model were significant. This provides strong support for the first hypothesis.

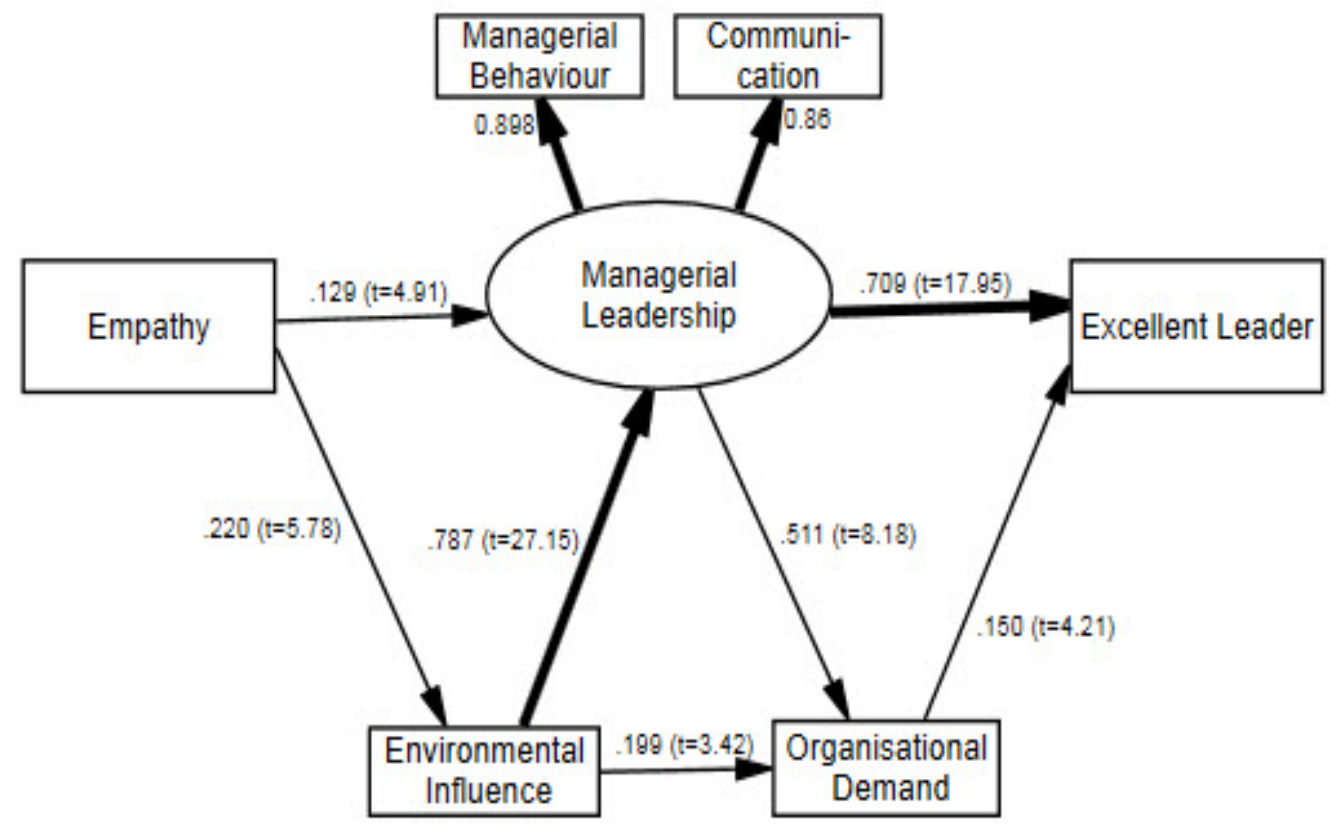

Figure 1 Structural Model with Beta Coefficients

A test of invariance across the two survey years shows that, although the measurement weights for the 2009 and 2014 surveys are similar for the managerial leadership construct (Chi-Square $=1.30, \mathrm{df}=3, \mathrm{p}=.729$ ), the same is not true for the structural weights (Chi-Square $=135.7, \mathrm{df}=5, \mathrm{p}<.001$ ). Significant differences are recorded in the first 3 rows of Table 7. In 2014, empathy had a significant negative impact on environmental influence and no significant impact on managerial leadership, whereas empathy had a significantly positive impact on both of these constructs in 2009. Finally, in support of Hypothesis 8, the effect of environmental influence on managerial leadership is much stronger in 2014 than 2009 as a result of the increasing environmental uncertainty. 
Table 7 Beta Weights for Figure $5(* p<.01)$

\begin{tabular}{|c|c|c|c|c|}
\hline & & BOTH & 2009 & 2014 \\
\hline Environmental Influence & Empathy & $.220 *$ & $.485 *$ & $-.230 *$ \\
\hline Managerial Leadership & Empathy & $.129 *$ & $.247 *$ & -.039 \\
\hline Managerial Leadership & Environmental Influence & $.787 *$ & $.661 \%$ & $.878 *$ \\
\hline Organisational Demand & Environmental Influence & $.199 *$ & $.193 *$ & .121 \\
\hline Organisational Demand & Managerial Leadership & $.511 *$ & $.504 *$ & $.621 *$ \\
\hline Managerial Behaviour & Managerial Leadership & $.898 *$ & $.893 *$ & $.917^{*}$ \\
\hline Communication & Managerial Leadership & $.860 *$ & $.837 *$ & $.885^{*}$ \\
\hline Excellent Leader & Managerial Leadership & $.709 *$ & $.699 *$ & $.627 *$ \\
\hline Excellent Leader & Organisational Demand & $.150 *$ & $.142 *$ & $.248 *$ \\
\hline \multicolumn{2}{|c|}{ R-Square for Excellent Leader } & $67 \%$ & $64 \%$ & $68 \%$ \\
\hline
\end{tabular}

As shown in Table 8, in 2009 and 2014, managerial leadership had the strongest influence on leadership excellence perceptions, thus supporting Hypothesis 5, while organisational demand had the least impact. The strength of the managerial leadership construct is further supported by two relationship constructs, namely managerial behaviours and good communication skills. The effect of environmental influence was much stronger in 2014 than in 2009, thus supporting Hypothesis 6 in that the effect of the GFC on the Bangladesh economy has had greater impact on managerial performance in 2014. Though weak, empathy is shown to have an effect on managerial leadership in both survey years, thus supporting Hypothesis 4. However, while the effect of empathy was positive in 2009, it was negative in 2014.

Table 8 Total Standardised Effect Sizes for Leadership Excellence with p-values and 95\% confidence intervals (CI) obtained using 2000 Bootstrap Samples

\begin{tabular}{|c|c|c|c|c|}
\hline & Empathy & $\begin{array}{c}\text { Environmental } \\
\text { Influence }\end{array}$ & $\begin{array}{l}\text { Managerial } \\
\text { Leadership }\end{array}$ & $\begin{array}{c}\text { Organisational } \\
\text { Demand }\end{array}$ \\
\hline \multirow{2}{*}{2009} & $.451 * *$ & $.537 * *$ & $.771^{* *}$ & $.142^{*}$ \\
\hline & $(.382-.512)$ & $(.453-.624)$ & $(.691-.840)$ & $(.016-.252)$ \\
\hline \multirow{2}{*}{2014} & $-.195 * *$ & $.715 * *$ & $.780 *$ & $.248^{*}$ \\
\hline & $(-.290-.097)$ & $(.650-.771)$ & $(.654-.861)$ & $(.097-.385)$ \\
\hline \multirow{2}{*}{ Both } & $.244 * *$ & $.648 * *$ & $.786^{* *}$ & $.150^{*}$ \\
\hline & $(.189-.300)$ & $(.597-.693)$ & $(.728-.834)$ & $(.057-.242)$ \\
\hline
\end{tabular}

\footnotetext{
$* \mathrm{p}<.05, * * \mathrm{p}<.01$
} 
Table 9 Support for Hypotheses

\begin{tabular}{|c|c|c|c|}
\hline Hypothesis & $\begin{array}{l}\text { Value statements which } \\
\text { support the hypothesis }\end{array}$ & $\begin{array}{l}\text { Statistic } \\
(95 \% \mathrm{CI})\end{array}$ & Support \\
\hline $\begin{array}{l}\text { H1. } \\
\text { Bangladesh managers } \\
\text { emphasise a multiplicity of } \\
\text { values that reflects personal, } \\
\text { managerial, organisational, and } \\
\text { environmental dimensions of } \\
\text { leadership excellence. }\end{array}$ & $\begin{array}{l}\text { Significant positive effect } \\
\text { sizes were obtained in Figure } \\
2 \text { for all these values, } \\
\text { together explaining a } \\
\text { substantial amount of the } \\
\text { variation in the Excellent } \\
\text { Leader construct. }\end{array}$ & $\begin{array}{l}\text { R-Square } \\
=67 \%(60 \%-72 \%)\end{array}$ & Yes \\
\hline $\begin{array}{l}\mathrm{H} 2 \text {. } \\
\text { The excellent leader in the } \\
\text { Bangladesh organization is } \\
\text { driven to continuously improve } \\
\text { performance. }\end{array}$ & $\begin{array}{l}\text { Continuous improvement is } \\
\text { the most important item in } \\
\text { the measurement model for } \\
\text { Excellent Leader in Table A1 }\end{array}$ & $\begin{array}{l}\text { Std weight } \beta \\
=.63(.56-.71)\end{array}$ & Yes \\
\hline $\begin{array}{l}\text { H3. } \\
\text { There will not be any difference } \\
\text { between the religious groups } \\
\text { perception of what constitutes } \\
\text { excellence in leadership in } \\
\text { Bangladesh. }\end{array}$ & $\begin{array}{l}\text { MANOVA test shows no } \\
\text { significant difference } \\
\text { between religious groups for } \\
\text { the scales in Table 3, with a } \\
\text { very small effect size (partial } \\
\text { eta-squared). }\end{array}$ & $\begin{array}{l}F(6,553)=1.65, \\
p=.134, \text { partial } \eta^{2} \\
=.017\end{array}$ & Yes \\
\hline $\begin{array}{l}\text { H4. } \\
\text { An excellent leader in } \\
\text { Bangladesh organisations will } \\
\text { exhibit values that are empathic } \\
\text { to the feelings of community. }\end{array}$ & $\begin{array}{l}\text { A weak but significant effect } \\
\text { size for Empathy in Table } 8\end{array}$ & $\begin{array}{c}\text { Total Std Effect } \\
\text { Size }=.24(.19-.30)\end{array}$ & Yes \\
\hline $\begin{array}{l}\text { H5. } \\
\text { Managerial leadership in } \\
\text { Bangladesh organisations is } \\
\text { influenced by relationship based } \\
\text { managerial behaviours and good } \\
\text { communication skills. }\end{array}$ & $\begin{array}{l}\text { A strong significant effect } \\
\text { size for Managerial } \\
\text { Leadership encapsulating } \\
\text { managerial and } \\
\text { communication skills in } \\
\text { Table } 8 .\end{array}$ & $\begin{array}{c}\text { Total Std Effect } \\
\text { Size }=.79(.73-.83)\end{array}$ & Yes \\
\hline $\begin{array}{l}\text { H6. } \\
\text { As the GFC impacts on the } \\
\text { Bangladesh economy the } \\
\text { responses of managers to } \\
\text { leadership excellence will differ } \\
\text { between } 2009 \text { and } 2014 \text {. }\end{array}$ & $\begin{array}{l}\text { MANOVA test shows a } \\
\text { significant difference } \\
\text { between the years for the } \\
\text { scales in Table } 3 \text {, with a } \\
\text { moderate effect size (partial } \\
\text { eta-squared). }\end{array}$ & $\begin{array}{c}\mathrm{F}(6,553)=11.85, \\
\mathrm{p}=<.001, \text { partial } \eta^{2} \\
=.110\end{array}$ & Yes \\
\hline
\end{tabular}


Table 9 Support for Hypotheses (continued)

\begin{tabular}{|c|c|c|c|}
\hline Hypothesis & $\begin{array}{l}\text { Value statements which } \\
\text { support the hypothesis }\end{array}$ & $\begin{array}{l}\text { Statistic } \\
(95 \% \mathrm{CI})\end{array}$ & Support \\
\hline $\begin{array}{l}\text { H7. } \\
\text { With increased globalisation } \\
\text { exposure, Bangladesh } \\
\text { organisational managers will } \\
\text { become less emphatic. }\end{array}$ & $\begin{array}{l}\text { ANOVA test shows a } \\
\text { significantly lower score } \\
\text { for empathy in } 2014 \text { than } \\
2009 \text { in Table 5, with a } \\
\text { moderate effect size (partial } \\
\text { eta-squared). }\end{array}$ & $\begin{array}{c}\mathrm{F}(1,556)=54.32 \\
\mathrm{p}=<.001, \text { partial } \eta^{2} \\
=.089\end{array}$ & Yes \\
\hline $\begin{array}{l}\text { H8. } \\
\text { Managers from the 2014-year } \\
\text { sample will associate excellence } \\
\text { in leadership more strongly with } \\
\text { EI-related dimension than will } \\
\text { the managers from the 2009- } \\
\text { year sample. }\end{array}$ & $\begin{array}{l}\text { Total Standardised effect } \\
\text { size for Environmental } \\
\text { Influence is significantly } \\
\text { higher in } 2014 \text { than } 2009 \text {. } \\
\text { The } 95 \% \text { confidence } \\
\text { intervals for these effect } \\
\text { sizes do not overlap }\end{array}$ & $\begin{array}{l}\text { Total Std. Effect Size in } \\
\qquad \begin{array}{l}2009=.537 \\
(.453-.624)\end{array} \\
\text { Total Std. Effect Size in } \\
2014=715 \\
(.650-.771)\end{array}$ & Yes \\
\hline
\end{tabular}

\section{DISCUSSION}

In this study, the four-dimensional framework suggested by Selvarajah et al. (1995) in their exploratory research of leadership excellence in Asia was applied to explore what constitutes excellence in leadership in Bangladesh organisations. Specifically, the paper considers the resilience of managerial leadership against the context of change and organisational adaptiveness. The four dimensions produced seven valid constructs to explain the cultural phenomenon observed in Bangladesh organisations. Reliable scales were developed for these constructs, and overall ratings for these constructs are high, confirming their importance.

The data was gathered across two time periods, 2009 and 2014, as we felt that this period check would provide the context for measuring the resilience of managerial leadership as measured against change and organisational adaptiveness. To provide variability, the data was gathered from the two main cities, Decca and Chittagong, across industries, private and public and non-government organisations, age, ethnicity, gender, and organisational managerial levels. The study clearly showed that, except for age and survey year, demographics did not significantly influence the perception of leadership excellence; with survey year being much stronger, even when all other demographics were controlled. 
In the following section, the contextual measures for managerial leadership in Bangladesh will be discussed in terms of an excellent leader and how time influences the managerial perceptions of what constitutes an excellent leader.

Firstly, we seek to address how an excellent leader is perceived in Bangladesh organisations. Secondly, we explain how the four dimensions of environment influences (EI), managerial behaviours (MB), organisational demands (OD), and personal qualities (PQ) impact what constitutes an excellent leader in Bangladesh organisations. Finally, we address the importance of time as a measure of managerial leadership perceptions influencing EI, MB, OD, and PQ. In furthering the discussion, it is important to affirm that no significant differences were found in the weights for the measurement model for the two surveys regarding excellent leader (ChiSquare $=8.66, \mathrm{df}=8, \mathrm{p}=.372$ ), environmental influences (Chi-Square $=7.98, \mathrm{df}=8$, $\mathrm{p}=.436$ ), managerial behaviours (Chi-Square $=20.135, \mathrm{df}=13, \mathrm{p}=.092$ ), and personal qualities (Chi-Square=14.38, $\mathrm{df}=11, \mathrm{p}=.213$ ). However, for the organisational demands measurement model, significant differences were found in the weights for the two surveys (Chi-Square $=24.42, \mathrm{df}=5, \mathrm{p}<.001$ ).

\section{Excellent Leader}

As shown in Appendix, Table A1, the most important excellent leader item is "Continues to learn how to improve performance" for both the 2009 and 2014 surveys. Respondents expressed clear and univocal support that organisational leaders need to be able to change, implement, and manage performance improvements on a continuous basis. This support is univocal in that organisational influences, whether from the outside or inside, must be in congruence with performance improvement. This univocal support by both year survey samples of the study on the need for continuous performance improvement supports the second hypothesis.

\section{Personal Qualities (PQ)}

PQ relates to the personal behaviour, attitudes, skills, values, and qualities of a person. In the Appendix, Table A5 shows two underlying scales: Communication and Empathy. No significant differences were found in the weights for this measurement models for the two surveys (Chi-Square $=14.38, \mathrm{df}=11, \mathrm{p}=.213$ ).

\section{- PQ-Communication}

In this research, managerial leadership encapsulates good communication skills as a determinant of an excellent leader in Bangladesh organisations. The statement that most reliably identifies this relationship in both the 2009 and 2014 surveys is "be 
practical." The results clearly show that communication has a strong relationship with managerial behaviour $(\mathrm{r}=0.777, \mathrm{p}<.001)$ and influences what constitutes an excellent leader through the qualities of managerial leadership. This relationship and its importance is diminished in the 2014 survey sample, indicating that there are factors other than demographics influencing the reduced effect of communication on what constitutes managerial leadership excellence in Bangladesh.

\section{- PQ-Empathy}

Empathy is identified most reliably by the items "Follows the heart not the head in compassionate matters" for both the surveys. Symbolically, Bangladeshi identity is centered on the 1971 struggle for independence from Pakistan. During that struggle, the key elements of Bangladeshi identity coalesced around the importance of the Bengali mother tongue and the distinctiveness of a culture or way of life connected to the floodplains of the region. Being Bangladeshi in some sense means feeling connected to the natural land-water systems of the Ganges, Brahmaputra, and other rivers that drain into the Bay of Bengal. In a sense, the two great Bengali poets Rabindranath Tagore and Kazi Nurul Islam have enshrined the beauty of the nation's togetherness. It is, however, disturbing to note that the same sense of emotional ability to understand and share the feelings of another has been eroded according to the 2014 survey response. In 2014, the same empathetic support has a negative impact on environmental influences, implying that there are conditions in the country influencing a change from a generous nature to more a business-like stand. This change effect is further emphasized in the environmental influences being much stronger on managerial leadership in the 2014 survey compared to the 2009 period.

\section{Environmental Influences (EI)}

EIs are etic or external factors that influence the operation of the entire organisation, such as politics and socio-economic and legal factors. The beta coefficients in Table A2 show the most dependable statement for identifying leaders in the environmental influence area for both the surveys, as "Constantly evaluates emerging technologies" was closely followed by "Studies laws and regulations which may have an impact on work." It is of interest to note that the 2014 survey year acknowledged the use of economic indicators for planning purposes as the most important statement supporting excellent leadership behaviour. The shift from an evaluation of emerging technologies to a position of monitoring economic changes could reflect the impact the GFC had on the economy. A reactionary rather than a 
proactive development stance is reflected in this change of leadership behaviour expected of managers.

\section{Managerial Behaviours (MB)}

MB relates to a person's organisational self in which the nature of work, actions, styles, values, and attitudes when performing the managerial duties clearly emphasizes the individualistic nature of this dimension. As shown in Table A3, the statements "Thinks about the specific details of any particular problem" and "Delegates" are the most reliable predictors of management behaviour for both surveys. However, delegating of work seems more favourable among the managers surveyed in the 2014 survey, while the 2009 surveyed managers were more supportive of concentrating on the details of solving a particular problem. This suggests that, though managers as leaders know what responsibilities to delegate whilst they are allowed more time to plan, the managers within a five-year time span have strengthened their resolve of the greater need to delegate. This shift from emphasising a particular problem to delegating and involving others is especially important in a developing nation, such as Bangladesh, where old hierarchical and patriarchal leadership styles prevail.

\section{Organisational Demands (OD)}

OD relates to the way a manager responds in a collective organisational setting to the structures, objectives, goals, and issues of an organisation. As shown in Table A4, the most reliable statement for identifying organisational demands is "Adjusts organisational structures and rules to the realities of practise" for both surveys. However, in the 2014 survey year, "Tells subordinates what to do and how to do it," with a difference in standardised weights of more than 0.20 , is a much stronger organisational measure supporting what constitutes excellence in managerial leadership in Bangladesh. This shift from adjusting organisational structures and rules to what happens in practice, to focusing on the performance of subordinates and helping overcome problems is reflective of an engaging and a change-oriented organisation. This response suggests a move away from a somewhat static position as reflected in the 2009 survey year response to a more dynamic organisation structure in 2014 survey year.

The responses may also suggest that there was more uncertainty in 2014 than in 2009 , with a greater need for leaders to adapt and guide subordinates. 


\section{IMPLICATIONS FOR THE PRACTICE}

There have been very few studies that have considered organisational development and the influence of change factors on managerial leadership behaviours. Though cultural changes can be slow, this study highlights that environmental effects on organisational performance can influence managerial perceptions of what constitutes excellence in leadership. In effect, this paper says that, apart from culture as a determinant of managerial behaviours, managers are also receptive to changes demanded by the environment on expected organisational behaviours.

Therefore, the generous nature of the system comes into question during times of restraint. Behavioural stance equally responds to these changes as a coping mechanism to self-preserve the system.

\section{THEORETICAL IMPLICATIONS OF THE STUDY}

This paper advances the resilience of managerial leadership and its ability to adapt to changing environmental conditions. In so doing, the Global Financial Crisis before and after effects on managerial leadership behaviours are tested. This paper provides an empirical understanding of environmental conditions on how managers respond to provide balance, continuity, and long-term viability of the firm. Thus, the strategies that managers chose and apply could be different and are influenced by changing conditions in the environment.

\section{LIMITATIONS OF THE STUDY}

The study is based on a single questionnaire containing 94 items in terms of leadership excellence and, as such, common variance bias may have affected the results. However, as acknowledged by Meade, Watson, and Kroustalis (2007), when CFA models are applied to 24 multitrait-multimethod correlation matrices, such bias is often minor in magnitude. The fact that the survey is repeated over two time periods after a five-year interval further reduces the risk of this bias. Also, the work of Siemsen, Roth, and Oliveira (2010) on multivariate linear relationships showed that common method bias decreases when additional independent variables are included in the regression equation. The excellence in leadership dimensions in this study were tested at the same time, suggesting that attention has been paid to common method variance. Furthermore, as we have acknowledged before (Selvarajah et al., 2017), in a study focused on the importance of leadership, it is not feasible to remove common method variance without removing the central theme of the research. 


\section{CONCLUSION}

In this paper, we have explored managerial leadership behaviours in Bangladesh organisations. In exploring excellence in leadership behaviours, the study has provided an organisational leadership model for Bangladesh during challenging times. In doing so, the social and spiritual traditions, as recommended by Rowley and Warner (2006), are woven into the organisational leadership qualities required by Bangladesh managers while seeking to direct the organisation through changing times. This link between culture, managerial leadership values, and stewardship has been the focus of this study and addresses a gap in the leadership studies field.

As such, this study is grounded on the principle that Bangladesh exhibits a blend of unique cultural and organisational characteristics that shape the managerial leadership context that drives excellence in leadership. Thus, this study has identified five EIL constructs that determine managerial leadership and what constitutes an excellent leader in Bangladesh organisations. To provide a deeper understanding of leadership excellence in Bangladesh, the socio-cultural interpretations of the leadership phenomenon were also added and analysed. For example, this study proposes that, while managerial behaviours and good communication are drivers of managerial leadership, empathy in the organisation is strongly affected by the influences from the environment. These results explain the need for managers to constantly evaluate their leadership styles, based on changes required in the organization, as a factor of constant changes in the environment.

The findings in this paper suggest that Bangladesh, an Islamic majority nation, is subjected to the external realities and thus, in a manner, is transforming Bangladesh managerial behaviors. The notions of time and environmental influences on managerial behaviors have not been the subject of leadership studies, and this study infers that these factors have influenced changing leadership behavioral values in Bangladesh. In addition, it appears during times when austerity is valued and empathy is sacrificed, thus allowing managers to be stronger headed rather than being led by the emotions of the heart.

\section{REFERENCES}

Ahmed, M. U. (2011). Globalization and Competitiveness of Bangladesh's Small scale Industries (SSIs): An Analysis of the Prospects and Challenges, in $\mathrm{CPD} / \mathrm{UPL}$ published, Bangladesh facing the Challenges of Globalisation, IRBD. 2-28.

Alam, S.M.S. (1993). Islam, Ideology, and the state in Bangladesh, Journal of Asian and African Studies, 28(1-2), 88-106. https://doi.org/10.1163/156852193X00433 
Ali, M. M., Islam, A. M. \& Wise, V. (2011). The great recession of 2008: impact on the Bangladesh economy and international business implications. Thunderbird International Business Review, 53(2), 263-276. https://doi.org/10.1002/tie.20405

Ali, M. M., \& Islam, A. M. (2010). Macroeconomic impacts of the global financial crisis on the Bangladesh economy. Savings and Development, 3(2010-XXXIV), 34(3), 305-342. https://www.jstor.org/stable/41803648

Allen, K. V., Frier, B. M. \& Strachan, M. W. J. (2004). The relationship between type 2 diabetes and cognitive dysfunction: longitudinal studies and their methodological limitations. European Journal of Pharmacology, 490, 169-175. https://doi.org/10.1016/j.ejphar.2004.02.054

Arbuckle, J., \& Wothke, W. (1999). AMOS 4 user's reference guide. Chicago: Small waters Corp.

Bangladesh Economic Update (2016), 1(5), Economic Policy Unit, Unnayan Onneshan.

Belias, D., \& Koustelios, A. (2014). The Impact of Leadership and Change Management Strategy on Organizational Culture, European Scientific Journal, 10(7), 451-470.

Berman, E., \& Prasojo, E. (2018). Leadership and Public Sector Reform in Asian Countries. Wagon Lane, Bingley, UK: Emerald Publishing Limited.

Bertocci, P.J. (2006). A Sufi movement in Bangladesh: The Maijbhandari tariqa and its followers, Indian Sociology, 40(1), 1-28. https://doi.org/10.1177/006996670504000101

Bhattacharya, D., Dasgupta, S. \& Neethi, D.J. (2012). Assessing the impact of the global economic and financial crisis on Bangladesh: An Intervention Analysis, CPD Working Paper 97, Centre for Policy Dialogue, Dhaka, Bangladesh. https://iris.unive.it/retrieve/handle/10278/43409/31683/GFC_BD_WP97.pdf.

Retrieved 18 February 2018

Choudhury, S.R. (2000) Knowledge management at shop floor level in Japanese multinationals - A cas study of Honda and Sanyo and their joint ventures in India. Journal of Scientific \& Industrial Research, 59, 720-731.

Fornell, C. \& Larcker, D. F., (1981). Evaluating structural equation models with unobservable variables and measurement error, Journal of Marketing Research, 18(1), 39-50. https://doi.org/ 10.2307/3151312

GED. (2016), Mid-Term Implementation Review of the Sixth Five Year Plan (201216) of Bangladesh, General Economic Division, Planning Commission, Government of Bangladesh, Dhaka July 2014. 
Hugue, A. S. (2007). Local leadership: Development, problems, and potential in Bangladesh. The Asia Pacific Journal of Public Administration, 29(2), 223-239. https://doi.org/10.1080/23276665.2007.10779336

Hair, J. F., Black, W. C., Babin, B. J., Enderson, R. E. \& Tatham, R. L. (2006). Multivariate Data Analysis (6th ed.),Upper Saddle River, NJ: Prentice Hall,

Hair, J. F., Hult, G. T. M., Ringle, C. M. \& Sarstedt, M. (2017). A Primer on Partial Least Squares Structural Equation Modeling (PLS-SEM) (2nd ed.) Thousand Oaks, CA:Sage.

Hall, R. (1991). Organizations: Structures, Processes, and Outcomes, $5^{\text {th }}$ edition, Englewood Cliffs, NJ: Prentice-Hall.

Hassan, M. (2012). Global political Islam in Bangladesh: past, present and future, Open Security: Conflict and Peacebuilding, 1 April. https://www.opendemocracy.net/opensecurity/mubashar-hasan/global-politicalislam-in-bangladesh-past-present-and-future. Accessed 19 May 2018.

Hodge, D. R. (2005). Social work and the house of Islam: Orienting practitioners to the beliefs and values of Muslims in the United States. Social Work. 50, 162-173. https://doi.org/10.1093/sw/50.2.162

Howitt, D., \& Cramer, D. (2011). Longitudinal Studies. Introduction to Research Methods in Psychology. $3^{\text {rd }}$ Edition. Harlow, England: Pearson.

Imam, M. O. (2009). Global financial crisis and its impact on the economy of Bangladesh. Management, 15(45), 5-11.

Islam, A., \& Quddus, M. (2008). Readymade garment exports: the Bangladeshi miraclee, IST Journal of Business and Technology, vol. 1, no. 1, December, pp. 18-27. 2008). Readymade garment exports: the Bangladeshi miracle"e, IST Journal of Business and Technology. 1(1), 18-27.

Jones, R., \& Mathew, S. K (2012). Toyotism and Brahmanism: Employee relations difficulties in establishing lean manufacturing in India. Employee Relations. 35(2), 200-221, https://doi.org/10.1108/01425451311287871

Khan, M. I. (2005). Social changes in contemporary Bangladesh. Journal of the Asiatic Society of Bangladesh. 58(2), 263-275.

Khan, S. H. (1999). United They Survive: Redistribution, Leadership and Human Services Delivery in Rural Bangladesh, Lanham: Lexington Books.

Lawrence, B. B. (1983). The early Chisti approach to sama. In Milton Israel and N.K.Wagle, eds, Islamic society and culture: Essays in honour of Professor Aziz Ahmed, 68-91. New Delhi: Manohar.

Mansur, A. H. (2011). Bangladesh economy in the midst of European financial crisis, Policy Research Institute, 21 December. http://www.pri- 
bd.org/main/view_publication/bangladesh-economy-in-the-midst-of-europeanfinancial-crisis_104. Retrieved 19 May 2018.

Meade, A. W., Watson, A. M. \& Kroustalis, C. M. (2007, April). Assessing Common Methods Bias in Organizational Research. Paper presented at the 22nd Annual Meeting of the Society for Industrial and Organizational Psychology, New York. Morishita, Y. (2001) Globalization and Japanese-Style Management, Global Communication Platform, Japanese Institute og Global Communication. http://www.glocom.org/opinions/essays/200108_morishita_globalization/index.h tml. Retrieved 19 May 2018.

Mukherjee, M., \& Pratap, K. (2009). The Impact of the global Financial Crisis on Investments in the Electric Power Sector: The Experience of India, Pakistan, and Bangladesh, Energy Sector Management Assistance Program (ESMAP) and World Bank. https://www.esmap.org/sites/esmap.org/files/SA\%20FINAL\%20REPORT\%20P DF.pdf. Retrieved 20 May 2018.

Murshid, K.A.S., Zohir, S.A., Ahmed, M. \& Mehedi, A.T.M.S. (2009). The Global Financial Crisis Implications for Bangladesh, Working Paper 1, Bangladesh Institute of Development Studies, Dhaka. http://citeseerx.ist.psu.edu/viewdoc/download?doi=10.1.1.476.1101\&rep=rep1\&t ype $=$ pdf. Retrieved 19 May 2018.

Nie, W., Xiao, D. \& Barsoux, J. (2017). Rethinking the East Asian leadership gap. MIT Sloan Management Review, 58(4), 87-88.

Patel, T., Salih, A. \& Hamlin R. G. (2018) Perceived managerial and leadership effectiveness in UAE and Egypt: A comparison through the combined lenses of Islamic work ethics and Islamic leadership. European Management Review. https://doi.org/ 10.1111/emre.12184

Rahman, M. A (2014). Globalization and Cultural Transformation: The Case of Bangladesh. Asian Culture and History. 6(2), Published by Canadian Centre of Science and Education.

Rahman, S., \& Salim, R. (2013). Six Decades of Total Factor Productivity Change and Sources of Growth in Bangladesh Agriculture (1948-2008). Journal of Agricultural Economics, 64(2), 275-294. https://doi.org/10.1111/14779552.12009

Reza, M. S., \& Khan, M. H. (2011), Impact of global financial crisis on the economy of Bangladesh, Bangladesh Journal of Political Economy, 27(1\&2), 61-83.

Riaz, A. (2004). God willing the politics of Islamism in Bangladesh, New Delhi: Rowan \& Littlefield Publishers Inc. 
Rowley, C., \& Warner, M. (2006). Business and Management in South East Asia: Studies in Diversity and Dynamism. Asia Pacific Business Review. 12(4), 389401. https://doi.org/10.1080/13602380600616057

Rowley, C., \& Ulrich, D. (2014). "Introduction: Setting the Scene for Leadership in Asia. In Leadership in the Asia Pacific, edited by Chris Rowley and Dave Ulich, 9-21. New York: Routledge.

Salahuddin, A., Khan, F.K. \& Akram, T. (2008). Legal, Regulatory, and Administrative Constraints to Employment Creation by Small \& Medium Enterprises in Bangladesh. Paper prepared for JOBS project, World Bank, Industrial Strategy Study: A Nationwide Industrial Survey.

Selvarajah, C., \& Meyer, D. (2017). Human capacity development in Indonesia: leadership and managerial ideology in Javanese organisations. Asia Pacific Business Review. 23(2), 264-289. https://doi.org/10.1080/13602381.2017.1299401

Selvarajah, C., Meyer, D., Roostika, R. \& Sukunesan, S. (2017) Exploring managerial leadership: Engaging Asta Brata, the eight principles of Indonesian statesmanship. Asia-Pacific Business Review, 23(3), 373-395. https://doi.org/10.1080/13602381.2016.1213494

Selvarajah, C., \& Meyer, D. (2006). Archetypes of the Malaysian manager: Exploring ethnicity dimensions that relate to leadership. Journal of Management and Organisation. 12(3), 251-256.https://doi.org/10.1017/S1833367200003990

Selvarajah, C., \& Meyer, D. (2008a). One nation, three cultures: Exploring dimensions that relate to leadership in Malaysia, Leadership \& Organization. $\begin{array}{lllll}\text { Development } \quad \text { Journal, } & \text { 29(8), } & 693 & - & 712 .\end{array}$ https://doi.org/10.1108/01437730810916

Selvarajah, C., \& Meyer, D. (2008b). Profiling the Chinese manager: Exploring dimensions that relate to leadership. Leadership and Organization Development Journal. 29(4), 359-375. https://doi.org/10.1108/01437730810876

Selvarajah, C., Duignan, P., Nuttman, C, Lane, T. \& Suppiah, C. (1995). In search of the ASEAN leader: Exploratory study of the dimensions that relate to excellence in leadership, Management International Review. 35(1), 29-43.

Selvarajah, C., Meyer, D. \& Davuth, D. (2012). The effect of cultural modelling on leadership profiling of the Cambodian Manager. Asia Pacific Business Review. 18(4), 649-674. https://doi.org/10.1080/13602381.2012.690256

Selvarajah, C., Meyer, D. \& Donovan, J. (2013b). Cultural context and its influence on managerial leadership in Thailand. Asia Pacific Business Review. 19 (3), 356380. https://doi.org/10.1080/13602381.2012.714630. 
Selvarajah, C., Meyer, D., Jeyakumar, R. \& Donovan, J. (2013a). Flowers in a greenhouse: Profiling excellence in leadership in Singapore. Leadership and Organizational Development Journal. 34(8), 784-804. https://doi.org/10.1108/LODJ-02-2012-0023.

Selvarajah, C., Meyer, D., Sukunesan, S. \& Venkatapathy, R. (2014). Rise of Indian Firms: Understanding leadership in Indian organizations. In T. S. Chan and Geng Cui (Eds), The Rise of Asian Firms (91-19), United Kingdom: Routledge.

Siemsen, E., Roth, A. \& Oliveira, P. (2010). Common method bias in regression models with linear, quadratic, and interaction effects. Organizational Research Methods, 13(3), 456-476. https://doi.org/10.1177/1094428109351241

Suwaydan, K. (2000). Monks and Islamic Sufism, Arab West Report. Egyptian Press summaries and media research for dialogue, Article 25. Rose al-Yusuf Publisher. http://www.arabwestreport.info/year-2000/week-19/25-monks-and-islamicsufism Retrieved 19 May 2018.

Terry, L. (2015). Leadership of Public Bureaucracies: The Administrator as Conservator, New York: Routledge.

Thai, T. M. and Carsten, N. H. (2015). How Institutions Influence SME Innovation and Networking Practices: The Case of Vietnamese Agribusiness. Journal of Small Business Management. 53(S1), 209-228. https://doi.org/10.1111/jsbm.12189

Turner, V. (1969). The Ritual Process, Chicago: Aldine.

Wood, G. D. (2007). Clashing Values in Bangladesh: NGOs, Secularism and the Ummah. Working Paper. Bath: ESRC Research Group on Wellbeing in Developing Countries. (Wellbeing in Developing Countries (WeD) Working Papers; WeD Working Paper 31). http://opus.bath.ac.uk/9750/ Retrieved 19 May 2018.

Zarruq, A; Istrabadi, Z. \& Hanson, H.Y. (2008). The Principles of Sufism. Amal Press: Baltimore US. 


\section{APPENDIX}

Table A1 Standardised Weights for Excellent Leader $(\mathrm{CMIN} / \mathrm{DF}=2.995, \mathrm{GFI}=.9727, \mathrm{CFI}=.94856, \mathrm{TLI}=.92738, \mathrm{RMSEA}=.06355, \mathrm{SRMR}=.039)$

\begin{tabular}{lllllr}
\hline No & \multicolumn{1}{c}{ Statement } & Combined & 2009 & 2014 \\
\hline a89 & $\begin{array}{l}\text { continue to learn how to improve } \\
\text { performance }\end{array}$ & $.633(.557-.708) 649$ & .626 & .642 \\
\hline a93 & $\begin{array}{l}\text { have confidence when dealing with work and } \\
\text { with people }\end{array}$ & $.594(.516-.670) 605$ & .602 & .568 \\
\hline a91 & $\begin{array}{l}\text { organise work time effectively } \\
\text { a82 }\end{array}$ & $\begin{array}{l}\text { develop strategies to gain competitive edge } \\
\text { in the industry }\end{array}$ & $.596(.512-.666) 588$ & .608 & .563 \\
\hline a29 & $\begin{array}{l}\text { give recognition for good work } \\
\text { a32 }\end{array}$ & have a strategic vision for the Organisation & $.525(.509-.663) 594$ & .588 & .572 \\
\hline a10 & be honest & $.476(.379-.570) 462$ & .433 & .439 \\
\hline a20 & $\begin{array}{l}\text { create a sense of purpose and enthusiasm in } \\
\text { the workplace }\end{array}$ & $.475(.378-.563) 298$ & .431 & .515 \\
\hline
\end{tabular}

Table A2 Standardised weights for Environmental Influence $(\mathrm{CMIN} / \mathrm{DF}=1.817, \mathrm{GFI}=.984, \mathrm{CFI}=.977, \mathrm{TLI}=.969, \mathrm{RMSEA}=.035, \mathrm{SRMR}=.030)$

\begin{tabular}{llrrr}
\hline No & \multicolumn{1}{c}{ Statement } & Combined & 2009 & 2014 \\
\hline a77 & constantly evaluate emerging technologies & .616 & .649 & .539 \\
\hline \multirow{2}{*}{ a70 } & $\begin{array}{l}\text { study laws and regulations which may have an impact on } \\
\text { work }\end{array}$ & .587 & .609 & .548 \\
\hline a66 & use economic indicators for planning purposes & .562 & .534 & $\mathbf{. 6 0 4}$ \\
\hline a27 & foster an international perspective in the Organisation & .539 & .550 & .541 \\
\hline a33 & identify social trends which may have an impact on work & .537 & .524 & .567 \\
\hline a78 & check consistently for problems and opportunities & .533 & .524 & .539 \\
\hline a30 & have a multi-cultural orientation and approach & .502 & .506 & .508 \\
\hline a16 & be socially and environmentally responsible & .402 & .372 & .441 \\
\hline a15 & be responsive to political realities in the environment & .390 & .344 & .494 \\
\hline
\end{tabular}


Table A3 Standardised Weights for Managerial Behaviour $(\mathrm{CMIN} / \mathrm{DF}=2.117, \mathrm{GFI}=.966, \mathrm{CFI}=.949, \mathrm{TLI}=940, \mathrm{SRMR}=.036, \mathrm{RMSEA}=.041)$

\begin{tabular}{|c|c|c|c|c|}
\hline No & Statement & Combined & 2009 & 2014 \\
\hline a22 & delegate & .608 & .577 & .658 \\
\hline a52 & $\begin{array}{l}\text { think about the specific details of any } \\
\text { particular problem }\end{array}$ & .599 & .618 & .548 \\
\hline a34 & keep up-to-date on management literature & .568 & .554 & .605 \\
\hline a13 & $\begin{array}{l}\text { be objective when dealing with work } \\
\text { conflicts }\end{array}$ & .541 & .546 & .549 \\
\hline a51 & tell subordinates what to do and how to do it & .534 & .537 & .516 \\
\hline a12 & be logical in solving problems & .516 & .498 & .503 \\
\hline a56 & use initiatives and take risks & .544 & .520 & .600 \\
\hline a7 & be consistent with making decisions & 496 & .435 & .559 \\
\hline a17 & $\begin{array}{l}\text { be strict in judging the competence of } \\
\text { employees }\end{array}$ & .478 & .503 & .408 \\
\hline a19 & consider suggestions made by employees & .460 & .408 & .581 \\
\hline a35 & $\begin{array}{l}\text { listen to and understand the problems of } \\
\text { others }\end{array}$ & .459 & .524 & .320 \\
\hline a9 & $\begin{array}{l}\text { be formal when dealing with employees at } \\
\text { work }\end{array}$ & .448 & .384 & .572 \\
\hline a39 & make decisions earlier rather than later & .416 & .376 & .537 \\
\hline a41 & make work decisions quickly & .412 & .372 & .476 \\
\hline
\end{tabular}

Table A4 Standardised weights for Organisational Demand $(\mathrm{CMIN} / \mathrm{DF}=3.039, \mathrm{GFI}=.995, \mathrm{CFI}=.973, \mathrm{RMSEA}=.056, \mathrm{SRMR}=.025)$

\begin{tabular}{clccc}
\hline No & \multicolumn{1}{c}{ Statement } & Combined & 2009 & 2014 \\
\hline \multirow{2}{*}{ a83 } & $\begin{array}{l}\text { adjust organisational structures and rules to the } \\
\text { realities of practice }\end{array}$ & .583 & $\mathbf{. 6 3 0}$ & .538 \\
\hline a50 & tell subordinates what to do and how to do it & .488 & .386 & $\mathbf{. 6 6 0}$ \\
\hline a23 & focus on maximising productivity & .456 & .514 & .352 \\
\hline a3 & adapt to changing working conditions & .440 & .330 & .586 \\
\hline a28 & give priority to long-term goals & .416 & .389 & .453 \\
\hline a94 & act as a member of the team & .352 & .299 & .479 \\
\hline
\end{tabular}


